\title{
Nursing Communication in Nursing Care to Mastectomized Women: a Grounded Theory Study ${ }^{1}$
}

\author{
lliana Maria de Almeida Araújo² \\ Raimunda Magalhães da Silva ${ }^{2}$ \\ Isabela Melo Bonfim² \\ Ana Fátima Carvalho Fernandes ${ }^{3}$
}

\begin{abstract}
The goal was to understand the nurse / patient communication process, emphasizing nursing care to mastectomized women. Symbolic Interactionism and Grounded Theory were used to interview eight nurses from a referral institution in cancer treatment, using the guiding question: how do nurses perceive their communication process with mastectomized women? Data analysis allowed for the creation of a central theory: the meaning of communication in nursing care to women, constituted by three distinct but inter-related phenomena: perceiving communication, the relationship nurse / mastectomized woman and rethinking the communication nurse / mastectomized woman. With a view to satisfactory communication, professionals need to get involved and believe that their presence is as important as the performance of technical procedures that relieve situations of stress.
\end{abstract}

Descriptors: Mastectomy; Nursing; Communication; Nursing Theory.

\footnotetext{
${ }^{1}$ Article extracted from Thesis Dissertation "O significado da comunicação na Assistência de Enfermagem à mulher mastectomizada: O olhar de quem cuida". Nursing Graduate Course, Universidade Federal do Ceará, Brazil.

2 RN, Ph.D., Faculty, Nursing Department, Universidade de Fortaleza, Brazil, e-mail: ilianama@hotmail.com, rmsilva@unifor.br, isabelambonfim@hotmail.com.

${ }^{3}$ RN, Ph.D. in Nursing, Faculty, Department of Nursing, Universidade Federal do Ceará, Brazil, e-mail: afanca@ufc.br.
}

Corresponding Author:

Ana Fátima Carvalho Fernandes

Departamento de enfermagem. Universidade Federal do Ceará

Rua Lauro Maia, 950 Complemento 402

Bairro José Bonifácio

CEP:60055-210 Fortaleza, CE, Brasil

E-mail: afanca@ufc.br 


\title{
A comunicação da enfermeira na assistência de enfermagem à mulher mastectomizada: um estudo de Grounded Theory
}

\begin{abstract}
Objetivou-se, aqui, compreender o processo de comunicação enfermeira/paciente, enfatizando a assistência de enfermagem à mulher mastectomizada. Foram usados o Interacionismo Simbólico e a Grounded Theory, para entrevistar oito enfermeiras de uma instituição de referência no tratamento do câncer, utilizando a questão norteadora: como a enfermeira percebe seu processo de comunicação com a mulher mastectomizada? A análise dos dados permitiu a criação da teoria central: o significado da comunicação na assistência de enfermagem à mulher, a qual se constitui de três fenômenos distintos que se inter-relacionam: percebendo a comunicação, a relação enfermeira/mulher mastectomizada e repensando a comunicação enfermeira mulher/mastectomizada. Entende-se que, para a comunicação ser satisfatória, a profissional precisa se envolver e acreditar que sua presença é tão importante quanto a realização de procedimentos técnicos os quais aliviam situações de estresse.
\end{abstract}

Descritores: Mastectomia; Enfermagem; Comunicação; Teoria de Enfermagem.

\section{La comunicación de la enfermera em la asistencia de enfermería a la mujer mastectomizada: um estudio de Grounded Theory}

El objetivo fue comprender el proceso de comunicación enfermera/ paciente, con énfasis en la asistencia de enfermería a la mujer mastectomizada. Se utilizó el Interaccionismo Simbólico y la Grounded Theory, para entrevistar ocho enfermeras de una institución con reconocido prestigio en el tratamiento de cáncer, utilizándose la siguiente pregunta: ¿Cómo la enfermera percibe su proceso de comunicación con la mujer mastectomizada? El análisis de los datos permitió la creación de la teoría central: el significado de la comunicación en la atención de enfermería a la mujer; esta se constituye de tres fenómenos diferentes que se interrelacionan: percibiendo la comunicación, la relación enfermera/mujer mastectomizada y repensando la comunicación enfermera/mujer mastectomizada. Así, se comprende que, para que la comunicación se torne satisfactoria, la profesional precisa envolverse y creer que su presencia es tan importante como la realización de procedimientos técnicos y que disminuye situaciones de estrés.

Descriptores: Mastectomía; Enfermería; Comunicación; Teoria de Enfermeria.

\section{Introduction}

In Brazil, in 2008, the estimated incidence of cancer among women was around 49,400 new cases, which corresponds to a gross rate of $52 \%$, only preceded by non-melanoma skin cancer. According to statistics, breast cancer remains one of the leading causes of death among women, following by lung, colon, rectal, cervical and stomach cancer. It represents the second most common malign tumor in the civilized world. In Ceará, the estimated number of cases is 1540/100,000, with $640 / 100,000$ in the state capital Fortaleza(1).

In contacts with women suffering from breast cancer, professionals need technical and communicative skills, as the interpersonal communication process is a unique event that should be valued as a nursing care instrument, working towards better adaptation to the disease and treatment with a view to the best possible quality of life for these women after the disease. Nurses are trained professionals to interact with mastectomized women and deliver individualized, humanitarian and comprehensive care ${ }^{(2)}$.

This assertion reveals not only the pathological problem itself, but also the fragility of women confronted with a severe and mortal disease. In view of breast cancer, women's social, family and self-relations go through a total change; hence, besides medical-hospital care, they need humanized care, capable of seeing them 
as people who suffer but have not lost their essence ${ }^{(3)}$.

It is well-known that nursing care to women with breast cancer should be seen as total, encouraging, affective care, committed to helping to adapt to new living conditions. To understand the situation of mastectomized women, face-to-face interaction is needed to understand these women's experiences in that situation(4).

Aware of the importance of communication in nursing work and the need to understand how professionals perceive their way of communicating with their clients, mainly when mastectomized women, in this research, the researchers attempted to understand the nurse/patient communication process, as it is believed that effective communication significantly contributes to elaborate, plan and put in practice higher quality care for these women. In view of the above, the research goal was to understand the nurse/patient communication process, emphasizing the signification, values and possibilities of change in care for mastectomized women.

\section{Theoretical-Methodological Framework}

This is an analytic study with a qualitative approach, with a view to understanding the results based on empirical explorations of communication in nursing care delivery to mastectomized women ${ }^{(5)}$. A qualitative design was chosen because, in this approach, approximation between the subject and the object is perceived. An additional goal was to find out how nurses perceive nurse/ patient communication with a view to the best possible adaptation to the disease and treatment. Thus, Symbolic Interactionism and Grounded Theory were chosen as the theoretical and methodological framework.

The eight nurses who participated in the study were interviewed in June and July 2006 at a referral hospital for cancer treatment in Fortaleza, CE. They were between 25 and 42 years old, responsible for nursing care at the service during this period, distributed across the three shifts and active at the hospitalization unit, recovery room, surgical center, ICU and outpatient clinic.

The sample size was based on the saturation of the testimonies contained in the interviews. In the theoretical sampling process, in line with Grounded Theory, there is a process in which the researcher, after collecting, coding and analyzing data in each sample group, defines what data still need to be collected and where these can be found(6-7). The nurses were identified by Arabic numerals, guaranteeing anonymity.

From the interactionist perspective, various procedures are used to collect data, considering exploration and inspection processes. In this research, free observation and semistructured interview were used for data collection. By using these techniques, the dynamics of the actual scenario was observed, and the context of the interpersonal relations nursing care occurred in was perceived. These conceptions were registered in a field diary.

Accordingtothepremisesofhumancommunication ${ }^{(8)}$, the following question was elaborated to guide the research: how do you perceive communication nurse/ mastectomized women during nursing care?

Data were organized manually, based on Grounded Theory, with the following steps: 1 - empirical data collection, 2 - concept formation, 3 - concept development, 4 - modified and integrated concepts and 5 - research report ${ }^{(8)}$.

To present the data, the components were used that constructed substantive theory, the signification of communication in nursing care for mastectomized women, involving three processes or phases: perceiving communication, relation nurse/mastectomized woman and rethinking communication nurse/woman/ mastectomized woman. Two expert judges on the theme were consulted to guarantee the credibility of the study and the identification of the interviewees' perceptions according to their reports. The first, a professor with a Ph.D. degree, surveyed the categories that were found and correspondence with the interviewees' discourse. The second, also a professor with a Ph.D. degree, analyzed the contents of the subcategories. This phase levered the credibility of the study.

Approval was obtained from the Ethics Committee for Research involving Human Beings, according to Resolution 196/96, respecting freedom to participate, secrecy and anonymity. Participants were informed about the research goal and properly signed the consent term.

\section{Results}

\section{Perceiving the communication nurse/mastectomized woman}

Communication is the process of sharing symbols and, also, apprehending their meanings and the nature of permanent change during the time it occurs( ${ }^{(9)}$.

In this process, it was observed that nurses use communication to get to know the women they are taking care of better and optimize their work, and that they link communication with basic professional instruments. To perceive the communication process, nurses attempted 
to create bonds ${ }^{(10)}$. This interaction between concepts emerged from one nurse's statement.

When I arrive at the service I visit the patients and, during this process, I see all pending items. I attempt to be as empathic as possible and give more time to patients who demand more attention, I attempt to give individualized care, according to each patient's needs (Enf 1).

Nurses see optimism as an attribute of people who should keep on fighting to continue their treatment ${ }^{(11)}$.

Communication is a process that mobilizes all human actions and is capable of supporting the organization and functioning of all social groups. Through the ability to perceive and communicate, people enrich their knowledge reference framework, transmit feelings and thoughts, clarify, interact and get to know what other people think and feel(12).

For me, communication is basic in any relation in our work, so, nursing is a profession that takes care of people and we can only take good care if we know our patients well and if they understand us too (Enf 2).

As the nurses in the research evidenced in their statements, communication is a fundamental tool for high-quality nursing care. For mastectomized women, everything is new and with so many changes occurring at the same time, these changes can produce conflicts. Hence, skills are needed to maintain individuality and the quality of care delivery ${ }^{(11)}$.

In this context, getting to know mastectomized women is not only presenting oneself to them, but understanding their needs resulting from the disease, treatment and changes in their personal, social, professional life, that is, it is something that transcends nursing and enters the roads of the interlocutors' self.

Nurses are fundamental in care for the women and the family. They are responsible for transmitting information focused on family restructuring, using communication as the main instrument ${ }^{(13)}$.

I have always thought about putting increasingly better care in practice. That is why getting to know these women and establishing a good relation with them is the road to follow. Communication opens the way for humanized care (Enf 3).

The mental reflection process says that social actors select, grant and transform meanings in the light of the situation they are in and the direction they imprint upon their action, based on their experiences ${ }^{(8)}$.

In this process, the nurses expressed the importance of creating empathy during nursing care, as conquering confidence and establishing significant bonds can contribute to quality care or not. It was revealed that these professionals had already awoken to the relevance of establishing true contact with these women, which makes it easier to maintain humanized and individualized care, as exposed in the following statement ${ }^{(14)}$.

Nurses should value each contact with the women, it is interesting that, in some situations, you just look and see that they are afraid, asking for you to stay around. This is serious! She doesn't have to say it. That does not mean that she cannot perceive when the professional is hiding, out of fear. To put humanization in practice, we need to put ourselves in the other person's place (Enf 4).

In nursing care, both interlocutors are human beings. Hence, any form of behavior communicates something to both, influences the other's behavior. Hence, the nurse's behavior, by not valuing effective communication, not valuing being together, looking and putting oneself in the other person's place, can definitely influence the behavior and values the woman attributes to the mastectomy experience ${ }^{(15)}$.

\section{The relationship nurse/mastectomized woman}

Nurses evidenced this relation by showing effectiveness in communication, involvement and coping with communication barriers.

As a professional, I have to seek this effectiveness in communication, although it is difficult. There are so many patients, each one reacts so differently that you always have to invent new things. There is no recipe, we live a different experience and learn a different lesson each day (Enf 5).

Nursing communication is permanently under construction and never repeats itself in the same way. The conditions are always different, with variations in one's own mood, willingness, place, time, space, as well as the in way patients' feelings are perceived(11).

In their statements, the participants built an idea of care delivery as a form of valuing the performance of their social roles, exposed in mastectomized women's acknowledgement of their value.

Seeking this involvement is fundamental. I think it's important even for the recognition of the profession. Nurses cannot complain of devaluation if they hide themselves from care. If you don't promote any (positive) change in the patient's life, how is she going to see your importance (Enf 6).

Mastectomy demands that women adjust their identity. Hence, nurses, as part of their social support network, play the fundamental role of participating in the construction process of this new identity, creating routes to enable women to face new phases in their lives.

In the different comparisons made for this process to emerge, professionals see the high level of patient and activity demands related to their roles as nurses 
as the main barrier to high-quality communication, as revealed by the following statements:

I cannot always sit down and talk due to the demand for activities that need to be performed during the shift. I do not always manage to be close to the patients, as there are so many, I attempt to set priorities, but it is not easy. Sometimes, there's a patient today whom you don't even have time to get closer to, then, during the other shift, she has already left (Enf 7).

Due to their work in a stressful environment, where patients are in risk situations, nurses often do not use communication resources as a therapeutic process. This means losing the opportunity to contribute to the approximation of hospital care, as recommended by the principles of the Unique Health System (SUS), which defends care integrality in parallel with the patient's recovery ${ }^{(15)}$.

It is fundamental, however, to highlight that the selfassessment process of their practice as nurses can serve as the north for the relationship nurse/mastectomized woman to follow new routes in the search for the best possible care.

\section{Rethinking the communication nurse/mastectomized woman}

As observed, the interlocutors in this process experience singular moments that can create changes in the meanings attributed to the moment both sides experience. One of the main functions of communication in nursing care is to establish significant relations.

By rethinking communication, nurses adopted the posture of remaining available and talking the same language in the interaction process.

I know that women with cancer go through hard times. That's why $I$ always attempt to assume the posture that it is my work to take care of them. I also try to listen to their anxieties. Sometimes they are quite shaken. Then I sit down and listen. The ideal, besides increasing professionals' availability, is to start this sensitization in undergraduate program, so that newly graduates get into the market with a more humane perspective on care (Enf 8).

Humanizing the experience of pain, suffering and loss demands something more from the nursing team, that is, the construction of therapeutic relations that permit relieving tensions and protecting the patient's dignity and values ${ }^{(15)}$.

Any human being has a self, which consists in the acknowledgement of his/her own concepts and other people's concepts about him/her. When going through certain situations, they assess, observe, interpret and formulate an individual or joint action ${ }^{(7)}$.
By looking from the perspective of nurse/ patient interactions in the condition of mastectomized women, the goal of care is for this woman to achieve a certain quality of life after the disease. This involves understanding the alterations in different spheres of their life. Understanding involves the complex process of social perception; it results in variable degrees of attraction and, finally, the social conflict can result from or lead to social communication ${ }^{(8)}$.

\section{Discussion}

The study about communication in nursing care delivery to mastectomized women revealed how nurses perceive communication, influencing their way of care delivery, attributing values and possibilities within care. Thus, the phenomena that are part of this central category emerged. In the first place, the process emerged in which nurses described how they perceive communication.

In this phenomenon, the nurses sought a way to get to know the women they were taking care of better through communication. By using this instrument to improve their work, the concepts emerged from the fact that they linked communication with the basic instruments of the profession, strengthening the concept according to which mastectomy is seen as a factor that produces different changes in women's lives. Therefore, knowledge with a view to better care is the route towards high-quality and humanized care.

In playing their role, nurses used their communication competency to put their relation with mastectomized women in practice. The better therapeutic and interpersonal communication strategies are used, the more effective this relation will be. But professionals should heed all factors that can be interacting during her unique moment of contact with those women.

The relevance of this care and of true interaction solidifies the human conducts of the women and the nurses. The therapeutic communication process serves as the source to potentiate, value and improve care. As observed, interaction and knowledge are benchmarks to make care effective, emerging from the construction of true and dynamic interpersonal relations.

Also, as observed, despite the relevance of interpersonal interaction, effective communication, participants also revealed their difficulties. It is perceived that difficulties to put in practice effective communication are related to activity demands, time and women and nurses' personal limitations, as well as some nurses' lack of preparation to communicate. It is, however, relevant 
to say that: the difficulties found derived from each nurse's experiences, and they are already aware and seek strategies to mitigate them. One of these strategies is the continuing professional training process.

To use dialogue as a strategy to transform health reality, nurses need to take hold of pedagogical techniques, particularly group techniques, defined as "a set of procedures that, when applied to a group situation, favors the achievement of group objectives: cohesion, interaction, productivity and group gratifications"(16).

Knowing the importance of therapeutic communication and its influence to re-establish patients' health, it should be assessed whether it takes place, with a view to the relevance of reflecting on the interfaces of this care for hospitalized patients, so as to contribute to the improvement of nursing care quality from the perspective of the communication process. Hence, the research results should be used to promote greater reflection among nurses about addressing aspects that favor interpersonal relations and, consequently, therapeutic communication ${ }^{(17)}$.

Asperceived, in the construction process of the theory, it was inserted in a dynamic construction/reconstruction through the process of rethinking communication nurse/ mastectomized woman. Significant relations are one of the main functions of communication in nursing care, establishing a relationship that can produce attitudinal and behavioral changes so as to satisfy communication partners' needs for inclusion, control and affection.

As communication is a nursing work instrument, it should be applied effectively in care delivery, independently of the hospitalization site and the level of complexity that person is in.

\section{Final Considerations}

Communication with mastectomized women is a challenge. Mainly because this interpersonal relationship is influenced by the meaning both women and nurses attribute to the process. The avalanche of changes in the patient's life resulting from the disease and treatment should also be taken into account. These will definitely affect the human behaviors they adopt.

Although mastectomized women face so many problems, nurses also face difficulties. They play several roles in one single context, and do not always use communication strategies to reach their goals. Not because they do not want to, but often because they do not know these strategies, do not feel capable or simply do not have the time needed for that.

When they refer to limitations in the communication process, the nurses also showed the possibilities of changes and emphasized the importance of professional qualification, of keeping up their academic life which, according to them, represents a source of great experiences. They mainly highlighted the need to awaken to the communication process as a nursing work instrument as early as during the undergraduate process, with a view to promoting the establishment of true and significant relations between students, nurses and patients.

As communication is such a comprehensive area, this study stimulates further research with a view to deepening and constructing knowledge on nursing team communication in care delivery to mastectomized women with a wide range of study objects, as no study was found in literature to address such a specific theme.

\section{References}

1. Instituto Nacional do Câncer. Ministério da Saúde. Câncer no Brasil: dados dos registros de base populacional. Rio de Janeiro (RJ): INCA; 2008.

2. Araújo IMA. Fernandes AFC. Enfrentando o diagnóstico de câncer de mama: depoimentos de mulheres mastectomizadas. Fortaleza: Editora UFC; 2005.

3. Moreira PL, Angelo M. Becoming a mother of a child with cancer: building motherhood. Rev Latino-am Enfermagem 2008 maio-junho; 16(3):355-61.

4. Wilson HS. Limiting intrusion-social control of outsiders in a healing community: an illustration of qualitative comparative analysis. Nurs Res 1977 March/April; 26(2):103-11.

5. Minayo MCS, Deslandes SF, Cruz Neto O, Gomes R. Pesquisa social: teoria, método e criatividade. Petrópolis: Vozes; 2002.

6. Blumer $\mathrm{H}$. Symbolic interactionism: perspective and method. Califórnia: University of Califórnia Press, Berkeley; 1969.

7. Littlejohn SW. Interacionismo Simbólico. In: Littlejohn SW.
Fundamentos teóricos da comunicação humana. Rio de Janeiro (RJ): Guanabara Koogan; 1988. p.65-86.

8. Strauss A, Corbin J. Basics of qualitative research: techniques and procedures for developing Grounded Theory. Califórnia: SAGE; 1990.

9. Stefanelli MC, Carvalho EC. A comunicação nos diferentes contextos da enfermagem. Barueri (SP): Manole; 2005.

10. O'Baugh J, Wilkes LM, Ludke S, George A. "Being positive": perceptions of patients with cancer and their nurses. J Adv Nurs [serial online] 2003 March [cited 2006 Out 20]; 44(3):262-70. Available from: URL:http://www3.interscience.wiley.com/cgibin/fulltext/118883557/PDFSTART

11. Andrade JS, Vieira MJ, Santana MA, Lima DM. A comunicação entre enfermeiros na passagem de plantão. Acta Paul Enferm 2004; 17(3):311-5.

12. Barcellos VR, Camponogara S. O uso da comunicação nãoverbal no cuidado ao paciente cardiopata: percepções da equipe 
de enfermagem. In: Costenaro RGS. Cuidando em enfermagem: pesquisas e reflexões. Santa Maria (RS): UNIFRA; 2001. p.53-72. 13. Sun FK, Long $A$, Huang $X Y$, Huang HM. Family care of Taiwanese patients who had attempted suicide: a grounded theory study. J Adv Nurs [serial online] 2007 November [cited 2006 Out 20]; 62(1):53-61. Available from: URL:http://www3. interscience. wiley.com/cgi-bin/fulltext/119403783/PDFSTART 14. Oliveira OS, Nóbrega MML, Silva AT, Ferreira MO Filha. Comunicação terapêutica em enfermagem revelada nos depoimentos de pacientes internados em centro de terapia intensiva. [On line] 2005 [citado 2006 Out 20]; Rev Eletr Enferm
2005; 7(1):54-63. Disponível em: http://www.revistas.ufg.br/ index.php/fen/article/view/861/1034.

15. Araújo MT, Silva MJP. A comunicação com o paciente em cuidados paliativos: valorizando a alegria e o otimismo. Rev Esc Enferm USP 2007 dezembro; 41(4):668-74.

16. Leonello VM, Oliveira MAC. Competencies for educational activities in nursing. Rev Latino-am Enfermagem 2008 marçoabril; 16(2):177-83.

17. Pontes AC, Leitão IMI, Ramos IC. Comunicação terapêutica em Enfermagem: instrumento essencial do cuidado. Rev Bras Enferm 2008 maio-junho; 61(3):312-8. 